\title{
ANALISA STABILITAS LERENG DAN ALTERNATIF PERKUATAN TANAH PADA JALUR KERETA API CEPAT JAKARTA-BANDUNG MENGGUNAKAN APLIKASI PLAXIS 8.6
}

\author{
Ainun Nafis', Eko Setyawan², dan Mohammad Musthofa Al Ansyorie ${ }^{3}$ \\ ${ }^{1}$ Universitas Negeri Malang, email: ainunnafis1@gmail.com \\ ${ }^{2}$ Universitas Negeri Malang, email: ekosetum@gmail.com \\ ${ }^{3}$ Universitas Negeri Malang, email: musthofansyorie.ft@um.a ${ }^{c . i d}$
}

\begin{abstract}
Abstrak: Masalah dalam perencanaan struktur jalan kereta seperti tinggi lereng embankment yang $\geq 6$ $\mathrm{m}$, tanah asli yang tergolong sedang lunak, dan merupakan daerah rawan terjadinya longsor merupakan alasan dilakukannya penelitian ini. Hal tersebut didukung oleh hasil uji lab tanah, kondisi geografis dan geologis Kabupaten Purwakarta berupa bukit dan lembah yang terbentuk dari endapan batuan sedimen dan aluvium vulkanik dengan kemiringan lahan $8-40 \%$. Oleh karena itu penelitian ini bertujuan untuk mengetahui stabilitas lereng embankment berupa nilai safety factor pada jalur kereta cepat Jakarta-Bandung daerah konstruksi DK70+150.00 sampai DK70+181.88. Adapun analisis numerik yang dilakukan pada penelitian ini menggunakan program Plaxis 8.6 yang dikembangkan berdasarkan metode Finite Element dengan model Mohr-Coulomb. Proses analisis dengan menginput parameter material yang dibutuhkan berdasarkan Mohr-Coulomb. Hasil analisis berupa angka safety factor yang menunjukkan kondisi stabilitas suatu lereng embankment. Penambahan alternatif perkuatan lereng embankment berupa cerucuk (micropile), bronjong (gabion) dan geotextile sebagai upaya pencegahan adanya kelongsoran jangka pendek dan panjang pada lereng embankment yang tidak stabil. Hasil analisis lereng embankment kereta api cepat Jakarta-Bandung DK70+150 sampai DK70+181.88 kondisi eksisting sebesar $\Sigma$ MSF $=1,1565$ (cek global) dan $\Sigma \mathrm{MSF}=1,0515$ (cek dinamik gempa) yang artinya lereng dalam kondisi tidak stabil dan perlu penambahan alternatif perkuatan. Berdasarkan simulasi kombinasi alternatif perkuatan. Menunjukkan kombinasi alternatif perkuatan geotextile dengan micropile menghasilkan angka safety factor $\Sigma \mathrm{MSF}=1,8151$ (cek stabilitas global) dan $\Sigma \mathrm{MSF}=1,6262$ (cek stabilitas akibat beban dinamik gempa).
\end{abstract}

Kata-kata kunci: stabilitas lereng embankment, Plaxis 8.6, safety factor, kereta cepat Jakarta-Bandung

Abstract: Problems in the design of the railway structure such as the embankment slope height of $6 \mathrm{~m}$, the original soil which is classified as moderately soft, and is an area prone to landslides is the reason for conducting this research. This is supported by the results of soil lab tests, geographical and geological conditions of Purwakarta Regency in the form of hills and valleys formed from sedimentary rock deposits and volcanic alluvium with a slope of $8-40 \%$. Therefore, this study aims to determine the stability of the embankment slope in the form of the safety factor value on the Jakarta-Bandung high-speed rail line in the construction area DK70+150.00 to DK70+181.88. The numerical analysis carried out in this study used the Plaxis 8.6 program which was developed based on the Finite Element method with the Mohr-Coulomb model. The analysis process by inputting the required material parameters based on Mohr-Coulomb. The results of the analysis are in the form of safety factor numbers which indicate the stability condition of an embankment slope. The addition of alternative reinforcement for embankment slopes in the form of micropile, gabion (gabion) and geotextile as an effort to prevent short and long term landslides on unstable embankment slopes. The results of the slope analysis of the Jakarta-Bandung high-speed rail embankment $D K 70+150$ to DK70+181.88 existing conditions of MSF $=1.1565$ (global check) and $M S F=1.0515$ (earthquake dynamics check) which means the slope is in an unstable condition and needs additional alternative reinforcement. Based on the simulation of alternative reinforcement combinations. Showing the alternative combination of geotextile reinforcement with micropile produces a safety factor number MSF $=1.8151$ (check global stability) and MSF = 1.6262 (check stability due to dynamic earthquake loads)..

Keywords: embankment slope stability, Plaxis 8.6, safety factor, Jakarta-Bandung high-speed train 


\section{PENDAHULUAN}

Padatnya jalur darat Jakarta-Bandung dan lama waktu tempuh menjadi kendala utama pengembangan potensi besar yang dimiliki Kota Bandung. Dengan keunggulan kereta cepat sebagai moda transportasi darat yang memiliki harga yang cukup terjangkau untuk berbagai kalangan serta kapasitas angkut penumpang/barang terbesar dalam sekali perjalanan, maka kereta cepat menjadi solusi terbaik untuk membangun konektivitas antar kota dan pembangunan kawasan potensial pada koridor Jakarta-Bandung. Jalur kerta cepat Jakarta-Bandung berada daerah rawan terhadap kejadian longsor. Hal ini di dukung oleh kondisi geografis dan geologis wilayah Kabupaten Purwakarta yang dilalui jalur kereta cepat adalah daerah berbukit, dan berlembah, dengan rata-rata kemiringan lahan $8-40 \%$, serta merupakan endapan batuan sedimen dan aluvium vulkanik (Ditjen PU Cipta Karya, 2018). Berdasarkan Peraturan Menteri Perhubungan Republik Indonesia Nomor PM. 60 Tahun 2012, dalam pembangunan jalur kereta api cepat ini ada beberapa syarat konstruksi yang harus terpenuhi diantaranya kondisi topografi dengan kelandaian 1,5\%, kemiringan tanah 5\%, dan kondisi tanah yang sesuai dengan spesifikasi.

Masalah yang terjadi pada pembangunan proyek ini yaitu badan jalan kereta merupakan lereng hasil timbunan (embankment) dengan ketinggian timbunan 8,26 $\mathrm{m}$ yang tergolong lereng embankment yang tinggi. Sehingga rawan terjadi hilangnya kestabilan akibat gerakan-gerakan tanah, retak-retak, kemiringan yang tidak sesuai dengan perencanaan, dan terjadi longsor karena kesalahan metode pemadatan. Hal ini sangat berbahaya bagi kereta saat melintas pada jalur tersebut, dikarenakan jalur kereta direncanakan untuk kendaraan dengan kecepatan tinggi yang mencapai $350 \mathrm{~km} / \mathrm{jam}$.

Untuk dapat menciptakan lereng yang stabil terhadap kelongsoran, maka jalur kereta cepat perlu melakukan perbaikan tanah dasar untuk menangani masalah pemampatan dan daya dukung dengan analisis menggunakan aplikasi Plaxis 8.6 yang dikembangkan berdasarkan metode elemen hingga. Output analisis Plaxis 8.6 berupa angka keamanan lereng (safety factor) yang menunjukan kondisi kestabilan lereng. Penambahan alternatif perkuatan tanah merupakan solusi pencegahan terjadinya kelongsoran lereng embankment.

Perencanaan perkuatan tanah timbunan dan pencegahan adanya longsoran pada lereng timbunan untuk jangka pendek dan panjang dipilih berdasarkan nilai safety factor dan nilai displacement. Ditinjau dari kuat tarik dan ketahanan terhadap faktor perkuatan geotextile lebih cocok mencegah terjadi kelongsoran lereng. Hal tersebut dikarenakan bahwa menggunakan geotextile pada tanah lunak khususnya lempung berfungsi sebagai perkuatan lereng, kekakuan, dan interaksi tanah geosintetik (friksi dan interlocking). Selain itu geotextile sangat efisien dilakukan pada bangunan baru, serta sangat sesuai digunakan untuk perkuatan konstruksi penulangan tanah di bawah ballas jalan rel (Ditjen PU Bina Marga, 2009). Selain geotextile, gabion juga berpotensi untuk mencegah terjadinya longsor. Pencegahan overall stablity terhadap timbunan menggunakan alternatif perkuatan Micropile digunakan agar embankmen aman (Fatah, 2018). 


\section{METODE}

\section{Rancangan Penelitian}

Dalam penelitian ini digunakan rancangan penelitian dengan pendekatan deskriptif kuantitatif. Pada penelitian ini yang akan diamati adalah hasil analisis stabilitas lereng akibat beban layan kereta yang melintas terhadap tanah timbunan pada lereng jalur kereta cepat Jakarta-Bandung DK70+150.00 sampai DK70+181.88 dengan perencanaan perkuatan tanah timbunan dengan cerucuk (micropile) dan pencegahan adanya longsoran pada lereng embankment dengan perkuatan geotextile dan bronjong (gabion) melalui program bantuan Plaxis 8.6. Sehingga dapat digambarkan secara jelas alternatif perkuatan yang akan direncanakan untuk kepentingan analisis yaitu terdiri dari tujuh opsi yaitu (1) cerucuk (micropile), (2) bronjong (gabion), (3) geotextile, (4) gabion dengan micropile, (5) geotextile dengan micropile, (6) gabion dengan geotextile, dan (7) micropile, gabion, dengan geotextile. Pemilihan penggunaan alternatif perkuatan berdasarkan nilai safety factor yang memenuhi syarat ketentuan.

\section{Objek dan Lokasi Penelitian}

Lokasi penelitian ini adalah lereng sebelah kiri jalur kereta cepat Jakarta-Bandung DK70+150.00 sampai DK70+181.88 yang bertepatan pada daerah Kab. Purwakarta.

\section{Metode Pengumpulan Data}

Metode pengumpulan data sekunder digunakan dalam penelitian ini adalah studi dokumen yang didapatkan tidak secara langsung dari subjek penelitian. Adapun data yang akan digunakan dalam proses penelitian adalah:

1) Layout lokasi studi kasus dan peta topografi.

2) Data hasil pengujian tanah dasar berupa parameter-parameter tanah yang diperlukan, seperti: kohesi tanah (c), berat volume $(\gamma)$, sudut geser dalam $(\phi)$, modulus young $(E)$, angka poisson (v).

3) Data beban kereta api (q), dan kecepatan kereta api (v) sebagai penentu asumsi beban statis kereta.

4) Data akselogram gempa

5) Data spesifiksi bahan/material dan parameter yang digunakan.

\section{Proses Analisis Data Penelitian}

Proses pengolahan data penelitian mencakup pengambilan data tanah, beban akibat kereta yang melintas, beban gempa, dan data spesifikasi alternatif perkuatan tanah dihitung secara manual dan langsung dari sumber data sekunder yang ditabelkan seperti Tabel 1 sampai 4.

Parameter data tanah yang diinputkan pada aplikasi Plaxis 8.6 untuk proses perhitungan tanah dasar dan tanah timbunan (Top Layer, Filler A, B, dan C, dan Bedding Layer) 
berupa data sifat fisik tanah berdasarkan model Mohr-Coulomb yaitu berat volume $(\gamma)$, kuat geser (c), sudut geser dalam ( $\phi)$, modulus young (E), angka poisson (v) yang didapat dari data sekunder Drilling log, data soil test, dan hasil uji tanah triaxial yang diperoleh dari hasil penyelidikan tanah oleh Laboratorium Pusat Proyek Kereta Api Cepat JakartaBandung.

Tabel 1. Rekapitulasi Data Tanah Eksisting (Tanah Dasar)

\begin{tabular}{lccccccccc}
\hline Depth & $\begin{array}{c}\text { Jenis Ta- } \\
\text { nah }\end{array}$ & $\mathbf{N - S P T}$ & $\gamma_{d}$ & $\gamma_{\text {sat }}$ & $\mathbf{C u}$ & $\boldsymbol{\theta}$ & $\boldsymbol{\Psi}$ & $\mathbf{E}$ & $\boldsymbol{v}$ \\
\hline $\mathbf{M}$ & & & $\mathbf{k N} / \mathbf{m}^{\mathbf{3}}$ & $\mathbf{k N} / \mathbf{m}^{\mathbf{3}}$ & $\mathbf{k N} / \mathbf{m}^{\mathbf{2}}$ & $\circ$ & $\circ$ & $\mathbf{k N} / \mathbf{m}^{\mathbf{3}}$ \\
\hline $0.00-2.70$ & Silt & 3 & 16.5 & 20.39 & 4.1 & 35.1 & 5.1 & 12400 & 0.25 \\
\hline $2.70-6.60$ & Silty Clay & 10 & 12.11 & 16.9 & 6.4 & 32.6 & 2.6 & 13800 & 0.3 \\
\hline $6.60-30.00$ & Clay Stone & 16 & 15.28 & 19.03 & 9.3 & 30.1 & 0.1 & 69000 & 0.35 \\
\hline
\end{tabular}

Sumber: Lab Central KCIC (2019)

Tabel 2. Rekapitulasi Data Tanah Timbunan

\begin{tabular}{|c|c|c|c|c|c|}
\hline Parameter & $\begin{array}{l}\gamma_{d} \\
\gamma_{s a t}\end{array}$ & Satuan & $\begin{array}{c}\text { Ballast } \\
\text { (Top Layer) }\end{array}$ & $\begin{array}{c}\text { Sub-Ballast } \\
\text { (Filler A, B, dan } \\
\text { C) } \\
\end{array}$ & $\begin{array}{c}\text { Timbunan Pilihan } \\
\text { (Bedding Layer) }\end{array}$ \\
\hline Berat Tanah Kering & & $\mathrm{kN} / \mathrm{m}^{3}$ & 25,5 & 22 & 15,9 \\
\hline Berat Tanah Jenuh & & $\mathrm{kN} / \mathrm{m}^{3}$ & 26 & 23 & 17 \\
\hline Modulus Young & $E$ & $\mathrm{kN} / \mathrm{m}^{3}$ & 450000 & 200000 & 10000 \\
\hline Angka Poisson & $\mathrm{v}$ & & 0,2 & 0,2 & 0,2 \\
\hline Kohesi Tanah & $\mathrm{Cu}$ & $\mathrm{kN} / \mathrm{m}^{2}$ & 600 & 67 & 15 \\
\hline Sudut Geser & $\theta$ & $\circ$ & 56 & 41 & 30,10 \\
\hline Sudut Dilatansi & $\Psi$ & $\circ$ & 26 & 11 & 0,10 \\
\hline
\end{tabular}

Sumber: Lab Central KCIC (2019)

Beban aksial kereta yang bekerja pada struktur badan jalan rel dihitung menggunakan beban gandar maksimum dengan berdasar Peraturan Menteri Perhubungan Nomor 60 Tahun 2012. Jalur Double track Jakarta-Bandung akan dibangun dengan lebar gandar $1067 \mathrm{~mm}$ dan menggunakan gaya gandar $(\mathrm{Pg})$ sebesar 17 ton. Sementara itu, kecepatan maksimum kereta api sebesar $350 \mathrm{~km} / \mathrm{jam}$. Untuk perencanaan jalan rel digunakan $\mathrm{V}$ rencana $300 \mathrm{~km} / \mathrm{jam}$.

Tabel 3. Distribusi Beban Aksial pada Ballast

\begin{tabular}{lcccccc}
\hline & \multicolumn{7}{c}{ Beban Aksial pada Ballast } \\
\cline { 2 - 7 } & $\mathrm{B} 1$ & $\mathrm{~B} 2$ & $\mathrm{~B} 3$ & $\mathrm{~B} 4$ & $\mathrm{~B} 5$ & $\mathrm{~B} 6$ \\
\hline Akibat Pd1 & $23 \%$ & $40 \%$ & $23 \%$ & $7 \%$ & $0 \%$ & $0 \%$ \\
\hline Akibat Pd2 & $0 \%$ & $7 \%$ & $23 \%$ & $40 \%$ & $23 \%$ & $7 \%$ \\
\hline Akibat Pd3 & $0 \%$ & $0 \%$ & $0 \%$ & $7 \%$ & $23 \%$ & $40 \%$ \\
\hline Total & $23 \%$ & $47 \%$ & $46 \%$ & $54 \%$ & $46 \%$ & $47 \%$ \\
\hline Total $(\mathrm{kN})$ & $\mathrm{Pd} \mathrm{x} \mathrm{23 \%}$ & $\mathrm{Pd} \times 47 \%$ & $\mathrm{Pd} \mathrm{x} \mathrm{46 \%}$ & $\mathrm{Pd} \times 54 \%$ & $\mathrm{Pd} \mathrm{x} \mathrm{46 \%}$ & $\mathrm{Pd} \times 47 \%$ \\
\hline Total $(\mathrm{kN})$ & 55.024 & 112.44 & 110.05 & 129.19 & 110.05 & 112.44 \\
\hline
\end{tabular}

Sumber: Hasil Perhitungan (2020) 


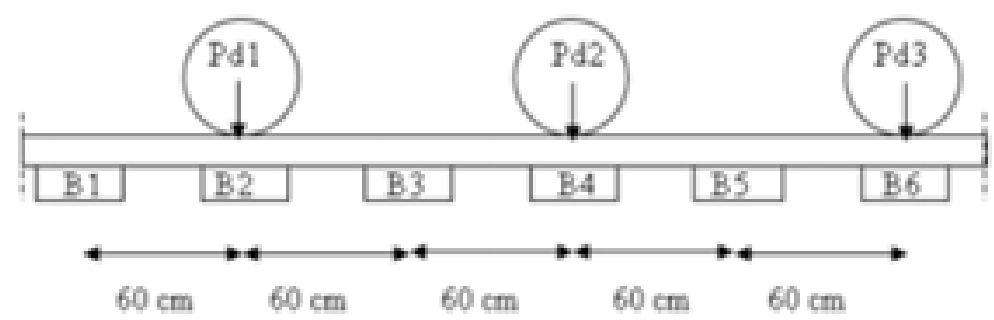

Gambar 1. Ilustrasi Distribusi Beban pada Bantalan Sumber: Profilidis, (2006)

Untuk perhitungan pembebanan selanjutnya digunakan beban maksimum, yaitu beban yang berada pada balas tepat di bawah roda sebesar $129.19 \mathrm{kN}$.

Berat rel kereta untuk tipe R54 adalah sebesar $0,535 \mathrm{kN} / \mathrm{m}$. Pada struktur jalan rel, terdapat 2 batang rel kereta sehingga berat total rel sebesar 1,0696 kN/m. Karena jarak antar bantalan adalah $60 \mathrm{~cm}$, beban rel kereta sebesar $60 \%$ beban per meter, yaitu $0,64 \mathrm{kN}$. Berat bantalan balok rel beton sebesar $200 \mathrm{~kg} / \mathrm{buah}$ setara dengan $2 \mathrm{kN} / \mathrm{m}$. Sehingga total beban dapat ditabelkan seperti Tabel 4.

Tabel 4. Rekapitulasi Beban

\begin{tabular}{|c|c|c|c|}
\hline \multirow[t]{4}{*}{1} & \multicolumn{3}{|l|}{ Beban Mati } \\
\hline & Rel & $=$ & $0.64 \mathrm{kN} / \mathrm{m}$ \\
\hline & Bantalan & $=$ & $2.00 \mathrm{kN} / \mathrm{m}$ \\
\hline & Jumlah & & $2.64 \mathrm{kN} / \mathrm{m}$ \\
\hline \multirow[t]{5}{*}{2} & Beban hidup & & \\
\hline & Kereta & $=$ & $129.19 \mathrm{kN} / \mathrm{m}$ \\
\hline & Jumlah & & $129.19 \mathrm{kN} / \mathrm{m}$ \\
\hline & Total & & $131.83 \mathrm{kN} / \mathrm{m}$ \\
\hline & Total Tiap Jalur & & $65.91 \mathrm{kN} / \mathrm{m}$ \\
\hline
\end{tabular}

Sumber: Hasil Perhitungan (2020)

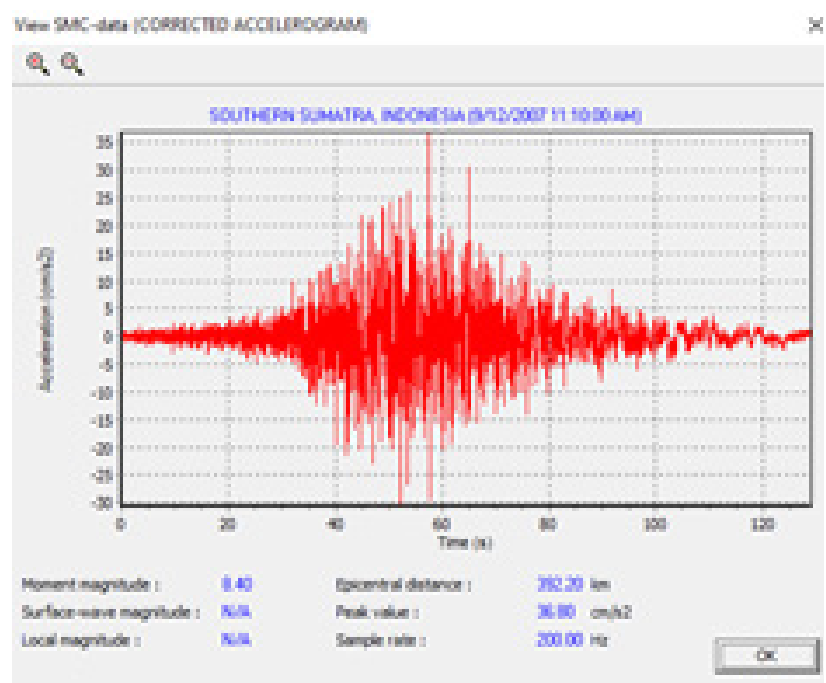

Gambar 2. Percepatan Gempa Desain Terkoreksi (USGS) Sumber: Strong-Motion Virtual Data Center USGS (2020) 
Salah satu syarat cek kestabilan lereng yaitu nilai safety factor hasil analisis Plaxis 8.6 dengan pengaruh beban dinamik gempa. Data gempa yang digunakan berbentuk data akselogram gempa stasiun Sumatera dengan format SMC (Strong Motion CD-ROM) yang didapat dari Strong-Motion Virtual Data Center USGS (United States Geologi Survey) dengan pendekatan Peak Ground Acceleration (PGA). Data gempa yang digunakan untuk proses analisis seperti pada Gambar 2.

Gambar 3 menjelaskan proses analisis stabilitas lereng dengan aplikasi Plaxis 8.6 berdasarkan metode elemen hingga (Finite Elemen Method) yang menggunakan model Mohr-Coloumb. Kelebihan proses analisis lereng tidak hanya memprediksi deformasi atau pergerakan tanah yang mungkin terjadi tetapi dapat juga mendapatkan nilai safety factor (SF) pada suatu lereng hasil hubungan tegangan regangan. Proses calculating dengan aplikasi Plaxis 8.6 dilakukan dengan dua macam analisis yaitu analisis dengan analisis Plastic dan Phi-C Reduction.

Sesuai Permen Peraturan Menteri Nomor 60 Tahun 2012 dan SNI 8460-2017 Persyaratan Perkuatan Geoteknik hasil output analisis nilainsafety factor pada tiap-tiap keadaan lereng $\geq 1,5$ untuk akibat beban statis dan nilai safety factor $(\mathrm{SF}) \geq 1,1$ untuk akibat beban dinamik gempa menunjukkan lereng dalam kondisi stabil, sehingga tidak perlu adanya penambahan perkuatan. Begitu sebaliknya nilai safety factor $(\mathrm{SF}) \leq 1,5$ dan nilai safety factor $(\mathrm{SF}) \leq 1,1$ menunjukkan lereng dalam kondisi rawan mengalami kelongsoran sehingga diperlukan adanya penambahan alternatif perkuatan.

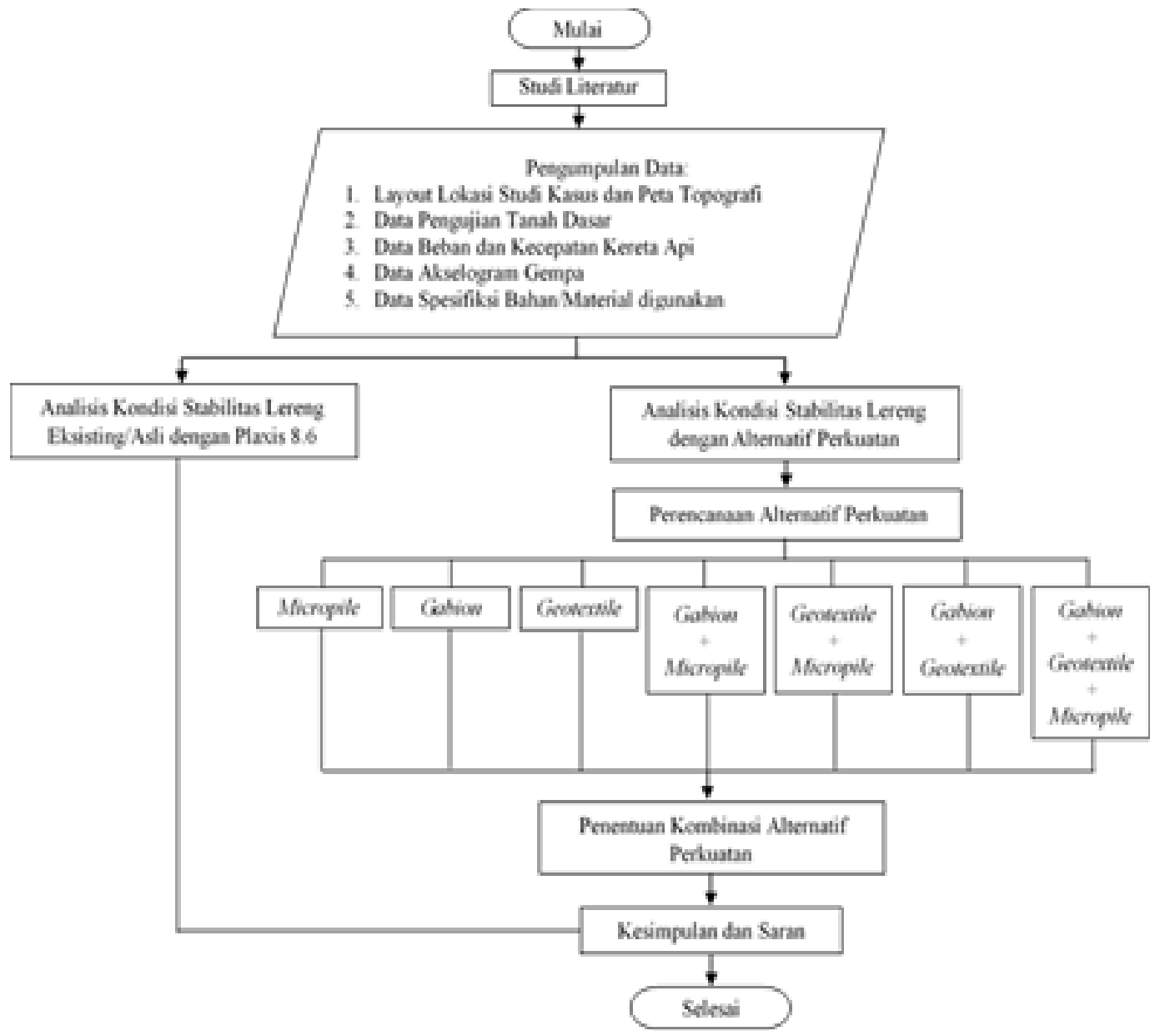

Gambar 3. Diagram Alir Penelitian 
Perencanaan perbaikan dan perkuatan tanah timbunan yang digunakan adalah cerucuk (Micropile). Sedangkan untuk perkuatan lereng menggunakan bronjong (Gabion), dan geotextile. Kombinasi alternatif perkuatan yang bertujuan untuk mencegah terjadinya longsor dapat digambarkan secara jelas alternatif perkuatan yang akan direncanakan untuk kepentingan analisis yaitu terdiri dari tujuh opsi yaitu (1) cerucuk (micropile), (2) bronjong (gabion), (3) geotextile, (4) gabion dengan micropile, (5) geotextile dengan micropile, (6) gabion dengan geotextile, dan (7) micropile, gabion, dengan geotextile. Pemilihan penggunaan alternatif perkuatan berdasarkan nilai safety factor yang memenuhi syarat ketentuan dan nilai dispalcemet yang kecil.

\section{HASIL}

\section{A.Analisis Stabilitas Lereng Embankment Kondisi Eksisting/Asli}

Analisis stabilitas lereng embankment kondisi eksisting yang direncanakan berdasarkan kondisi tanah asli yang sudah ditimbun dengan tanah timbunan pilihan dengan adanya pengaruh beban kereta yang melintas pada lereng embankment DK70+150.00 sampai DK70+181.88.

Analisis ini dilakukan berdasarkan data desain gambar teknik geometri perencanaan jalur kereta cepat Jakarta-Bandung DK70+150.00 sampai DK70+181.88 seperti pada Gambar 4. dan penggambaran pemodelan geometri lereng embankment kondisi eksisting/asli dengan pengaruh beban kereta cepat yang melintas melalui program bantu Plaxis 8.6 dapat dilihat pada Gambar 5.

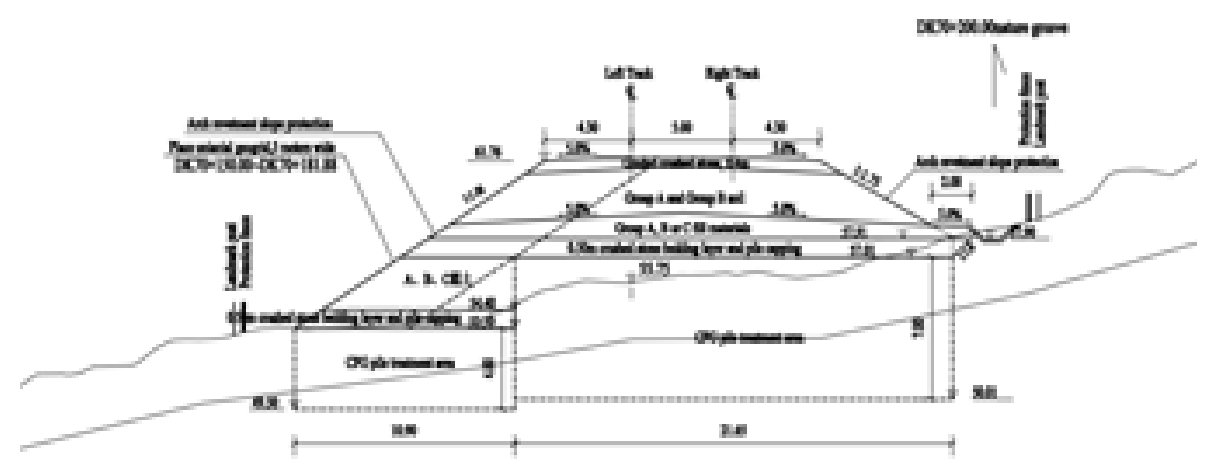

Gambar 4. Geometri Lereng Embankment DK70+150 sampai DK70+181.88 Sumber: Laporan Perencanaan Kereta Api Cepat Jakarta-Bandung

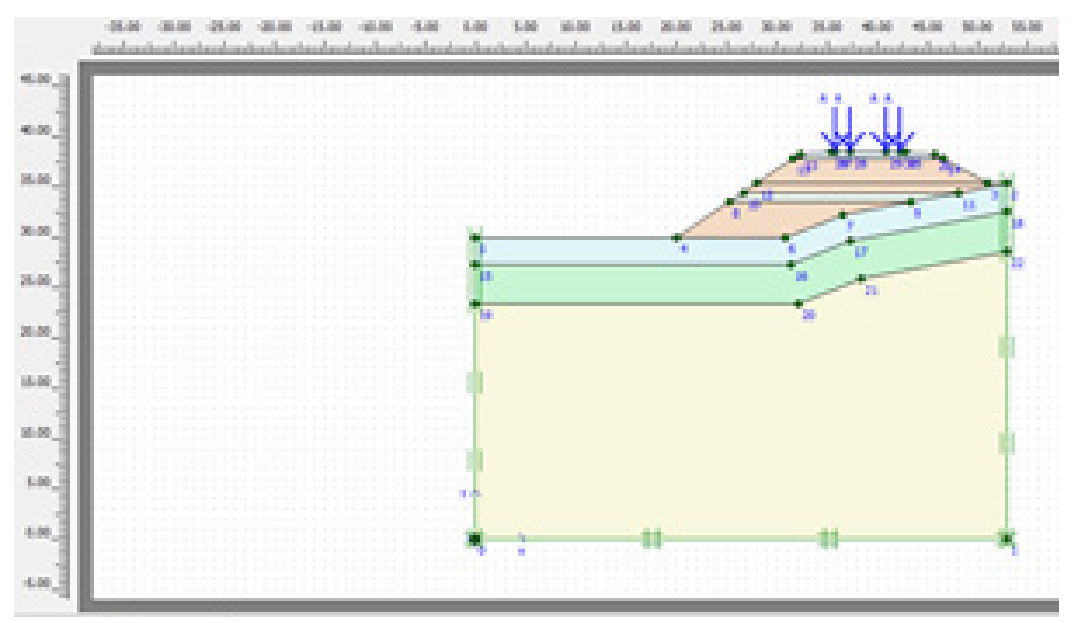

Gambar 5. Pemodelan Lereng Embankment DK70+150 sampai DK70+181.88 dengan Pengaruh Beban yang Melintas

Sumber: Plaxis 8.6 (2020) 
Dari hasil analisis dua kondisi tersebut, dengan menggunakan program bantu Plaxis 8.6 dapat ditabelkan untuk merekap nilai safety factor yang diperoleh dari hasil output Plaxis 8.6 seperti yang ditunjukkan pada Table 5.

Tabel 5. Nilai Safety factor pada DK70+150.00 sampai DK70+181.88 Kondisi Eksisting

\begin{tabular}{lcc}
\hline \multicolumn{1}{c}{ Lokasi } & Sisi Lereng & SF \\
\hline Lereng embankment dengan beban akibat kereta yang melintas & Kiri & 1.1565 \\
\hline $\begin{array}{l}\text { Lereng embankment dengan beban akibat kereta yang melintas dan } \\
\text { keadanya pengaruh beban dinamik gempa }\end{array}$ & Kiri & 1.0515 \\
\hline
\end{tabular}

Sumber: Hasil Perhitungan (2020)

\section{B. Analisis Stabilitas Lereng Embankment dengan Alternatif Perkuatan}

Analisis stabilitas lereng embankment dengan alternatif perkuatan dilakukan jika lereng embankment dalam kondisi tidak stabil atau rawan terjadi kelongsoran. Alternatif perkuatan yang akan digunakan sebagai solusi meminimalisir kelongsoran yaitu berupa (1) cerucuk (micropile), (2) bronjong (gabion), (3) geotextile, (4) gabion dengan micropile, (5) geotextile dengan micropile, (6) gabion dengan geotextile, dan (7) gabion, geotextile, dengan micropile. Acuan dalam perhitungan kebutuhan perkuatan tanah timbunan maupun lerengnya berdasarkan hasil analisis kondisi eksisting dengan pengaruh beban kereta yang melintas menggunakan aplikasi Plaxis 8.6.

Perencanaan perkuatan yang dilakukan pada tanah timbunan pembentuk embankment dalam kondisi eksisting/asli tersebut akan menggunakan metode perbaikan cerucuk (Micropile). Sedangkan perkuatan untuk lereng timbunannya menggunakan metode geotextile atau gabion. Untuk menciptakan lereng embankment yang stabil maka perlu dilakukan cek kestabilan sesuai dengen peraturan Pedoman Perencanaan dan Pelaksanaan Perkuatan Tanah dengan Geosintetik No. 003/BM/2009. Berikut penjelasan untuk kebutuhan perkuatan tanah timbunan dan lereng embankment DK70+150.00 sampai DK70+181.88.

Dari tujuh macam opsi kombinsi dari alternatif perkuatan yang dilakukan dapat ditabelkan dari hasil rekapan analisis stabilitas lereng embankment seperti pada Tabel 6 .

Tabel 6. Rekapitulasi Hasil Analisis Stabilitas Lereng Embankment

\begin{tabular}{llllll}
\hline No. & Pemodelan & \multicolumn{1}{c}{ Kondisi } & Nilai SF & Syarat & \multicolumn{1}{c}{ Ket. } \\
\hline \multirow{2}{*}{1} & Eksisting/Asli & Cek stabilitas global & 1.1565 & 1.5 & Tidak Stabil \\
\cline { 3 - 6 } & & Cek stabilitas dinamik gempa & 1.0515 & 1.1 & Tidak Stabil \\
\hline 2 & $\begin{array}{l}\text { Cerucuk (Mi- } \\
\text { cropile) }\end{array}$ & Cek stabilitas global & 1.2735 & 1.5 & Tidak Aman \\
\cline { 2 - 6 } & Cek stabilitas dinamik gempa & 1.0751 & 1.1 & Tidak Aman \\
\hline \multirow{3}{*}{$\begin{array}{l}\text { Bronjong } \\
\text { (Gabion) }\end{array}$} & Cek Ketahanan Tekanan Aktif & 1.494 & 1.5 & Tidak Aman \\
\cline { 3 - 6 } & & Cek Guling & 1.5 & 1.5 & Aman \\
\cline { 3 - 6 } & & Cek Geser & 1.983 & 1.5 & Aman \\
\cline { 3 - 6 } & & Cek Stabilitas Global Gabion & 1.3729 & 1.5 & Tidak Aman \\
\cline { 3 - 6 } & & Cek Stabilitas Dinamik & 1.107 & 1.1 & Aman \\
\hline
\end{tabular}


Lanjutan Tabel 6. Rekapitulasi Hasil Analisis Stabilitas Lereng Embankment

\begin{tabular}{llllll}
\hline No. & \multicolumn{1}{c}{ Pemodelan } & \multicolumn{1}{c}{ Kondisi } & Nilai SF & \multicolumn{1}{c}{ Syarat } & \multicolumn{1}{c}{ Ket. } \\
\hline 4 & Geotextile & Cek Geser & 1.53 & 1.5 & Aman \\
\cline { 3 - 6 } & & Cek Guling & 1.8 & 1.5 & Aman \\
\cline { 3 - 6 } & & Cek Stabilitas Global & 1.5007 & 1.5 & Aman \\
\cline { 3 - 6 } & & Cek stabilitas dinamik gempa & 1.1547 & 1.1 & Aman \\
\cline { 3 - 6 } & & Cek Tahanan Cabut & 3.6 & 1.5 & Aman \\
\hline \multirow{2}{*}{5} & Gabion dan Micropile & Cek stabilitas global & 1.5416 & 1.5 & Aman \\
\cline { 3 - 6 } & & Cek stabilitas dinamik gempa & 1.3422 & 1.1 & Aman \\
\hline \multirow{2}{*}{\begin{tabular}{l} 
Geotextile dan Micro- \\
\cline { 3 - 6 }
\end{tabular}} & pile & Cek stabilitas global & 1.8151 & 1.5 & Aman \\
\cline { 3 - 6 } & Gabion dan Geotextile & Cek stabilitas dinamik gempa & 1.6262 & 1.1 & Aman \\
\cline { 3 - 6 } & & Cek stabilitas global & 1.7524 & 1.5 & Aman \\
\hline \multirow{2}{*}{8} & Gabion, Geotextile dan & Cek stabilitas dinamik gempa & 1.5943 & 1.1 & Aman \\
\cline { 3 - 6 } & Micropile & Cek stabilitas global & 1.9463 & 1,5 & Aman \\
\hline
\end{tabular}

Sumber: Hasil Perhitungan (2020)

\section{PEMBAHASAN}

Berdasarkan hasil pemodelan stabilitas lereng yang direncanakan stabilitas lereng tanah eksisting serta penanganan kelongsorannya dengan beberapa alteratif perkuatan tanah lereng embankment berupa serucuk (Micropile), bronjong (Gabion) dan Geotextile yang dianalisis dengan program aplikasi Plaxis 8.6.

\section{A. Stabilitas Lereng Embankment Kondisi Eksisting/Asli}

Dari hasil running tabel 6 pemodelan lereng embankment dengan ketinggian embankment $8.26 \mathrm{~m}$ yang analisis berdasarkan data desain gambar geometri perencanaan jalur kereta cepat Jakarta-Bandung DK70+150.00 sampai DK70+181.88 menjelaskan bahwa nilai safety factor hasil analisis lereng embankment eksisting/asli melalui program bantu Plaxis 8.6 memiliki nilai safety factor sebesar $\Sigma \mathrm{SMF}=1,1565$. Sedangkan dengan adanya pengaruh beban dinamik gempa nilai $\Sigma \mathrm{SMF}=1,0515$.

Nilai safety factor output hasil analisis cek stabilitas global dan dinamik gempa pada jalur kereta cepat Jakarta-Bandung pada DK70+150 sampai DK70+181.88 memiliki nilai safety factor $\leq 1,5$ dan $\leq 1,1$. Hal tersebut menjelaskan bahwa belum memenuhi syarat Peraturan Menteri Nomor 60 Tahun 2012.

Hasil penelitian Muzakki (2017) menjelaskan bahwa daerah konstruksi jalur kereta cepat Jakarta-Bandung berada pada daerah rawan kelongsoran. Hal tersebut dibuktikan dengan kondisi geografis yang dilewati oleh jalur kereta cepat Jakarta-Bandung yaitu daerah bukit dan lembah dengan tipe tanah sedang dan lunak.

Dapat disimpulkan bahwa jalur kereta cepat Jakarta-Bandung pada DK70+150.00 sampai DK70+181.88 pada kondisi eksisting terjadi kelongsoran pada lereng embank- 
ment, artinya lereng tersebut sesuai desain eksisting tidak menumpu menerima beban statis kereta dan struktur jalan rel sebesar 65.91 ton. sehingga perlu penambahan alternatif perkuatan lereng embankment untuk mencegah terjadinya kelongsoran.

\section{B. Stabilitas Lereng Embankment Akibat Penambahan Alternatif Perkuatan}

Hasil analisis lereng embankment dengan kondisi eksisting menunjukkan lereng embankment mengalami kelongsoran dan perlu adanya penambahan alternatif perkuatan. Perencanaan penambahan alternatif perkuatan pada lereng embankment merupakan upaya dalam menciptakan stabilitas lereng tanah bertulang (reinforcement soil) untuk memenuhi nilai safety factor dan mengurangi deformasi akibat beban rencana kereta cepat yang melintas.

\section{Stabilitas Lereng dengan Alternatif Perkuatan Cerucuk (Micropile)}

Sesuai rekapitulasi pada Tabel 6 analisis pemodelan lereng embankment yang dilakukan berdasarkan data desain gambar geometrik perencanaan jalur kereta cepat JakartaBandung DK70+150.00 sampai DK70+181.88 menjelaskan bahwa lereng embankment alternatif pekuatan micropile kondisi eksisting/asli dengan pengaruh beban kereta cepat yang melintas melalui program bantu Plaxis 8.6 memiliki nilai safety factor sebesar $\Sigma$ SMF $=1,2735$. sedangkan nilai safety factor dengan adanya pengaruh beban dinamik gempa $\Sigma \mathrm{SMF}=1,0751$. Hasil output analisis Plaxis 8.6 dengan alternatif perkuatan cerucuk (micropile) memiliki nilai safety factor $\leq 1,5$ untuk cek satbilitas global dan $\leq 1,1$ untuk cek stabilitas terhadap beban dinamik gempa (dibawah nilai minimum standart yang ditentukan). Menurut Peraturan Menteri Nomor 60 Tahun 2012 menjelaskan bahwa nilai safety factor suatu lereng tanah dengan asumsi tingkat ketidakpastian kondisi analisis pada ruas jalur kereta cepat Jakarta-Bandung pada DK70+150.00 sampai DK70+181.88 dengan kondisi lereng tidak stabil atau rawan terjadi kelongsoran.

Hasil penelitian Rusdiansyah (2016) menunjukkan perkuatan cerucuk yang efektif untuk mengatasi stabilitas lereng dengan cara menghambat pergeseran tanah akibat gaya horizontal yang terjadi pada bidang longsornya menggunakan perkuatan tiang-tiang vertikal yang berperilaku mengatasi overall stability.

Dari pernyataan diatas menjelaskan bahwa karena tinggi lereng yang tergolong lereng tinggi ( $\geq 6 \mathrm{~m}$ ) maka membutuhkan perkuatan yang bisa mengurangi pergeseran akibat beban vertkal dan horizontal yang diterima struktur jalan. Sehingga alternatif perkuatan micropile ini tidak dapat diaplikasikan pada kondisi lapangan jalur kereta cepat dengan tinggi lereng embankment $8.26 \mathrm{~m}$ yang dominasi tanah timbunan dan membutuhkan alternatif perkuatan lainnya untuk mengatasi keruntuhan pada lereng embankment. 


\section{Stabilitas Lereng dengan Alternatif Perkuatan Bronjong (Gabion)}

Dalam perencanaan alternaif perkuatan bronjog (gabion) yang digunakan adalah gabion tipe box yang menggunakan prinsip gravitasi. Analisis yang dimodelkan sesuai perencanaan geometrik eksisting diharapkan sebagai opsi alternatif perkuatan lereng embankment nilai stabilitas yang diisyaratkan sesuai Peraturan Menteri Nomor 60 Tahun 2012. Output analisis menggunakan Plaxis 8.6 dengan alternatif perkuatan lereng embankment dapat dilihat pada Tabel 4.22.

Berdasarkan hasil analisis pemodelan lereng embankment yang dilakukan berdasarkan data desain gambar geometrik perencanaan jalur kereta cepat Jakarta-Bandung DK70+150.00 sampai DK70+181.88 pada Tabel 4.22 nilai output stabilitas lereng embankment melalui program bantu Plaxis 8.6 sebesar $\Sigma \mathrm{SMF}=1,3729$ dan output dengan adanya pengaruh beban gempa memiliki nilai safety factor $\Sigma \mathrm{SMF}=1,1070$. Hasil analisis dapat dijelaskan bahwa nilai safety factor hasil output analisis Plaxis 8.6 masih dibawah standar minimum yang ditentukan menurut Peraturan Menteri Nomor 60 Tahun 2012. Cek syarat stabilitas global belum memenuhi syarat yang berlaku, tetapi pada cek stabilitas akibat beban dinamik gempa memiliki nilai safety factor yang memenuhi dengan perbedaan angka yang sangat kecil yaitu 0.0070 dari syarat minimum. Sehingga stabilitas lereng embankment akibat beban dinamik gempa dianggap belum memenuhi syarat ketentuan.

Menurut Prayitno (2016) Data analisis menggunakan kombinasi pemodelan gabion gravitasi dan gabion terramesh pada tingkatan lereng dengan data tanah hasil korelasi N-SPT. Hasil analisis didapatkan peningkatan angka keamanan diperkuat gabion ditunjukkan pemodelan gabion terramesh atau dengan megubah sudut lereng jadi lebih landai.

Dari hasil analisi dan pernyataan penelitian diatas, solusi perkuatan gabion hasil output analisis merupakan hasil perencanan dengan mengubah sudut perencanaan menjadi $48^{\circ}$. Karena pertimbangan tinggi lereng yang lebih dari $6 \mathrm{~m}$, maka alternatif perkuatan bronjong (gabion) pada lereng embankment dalam kondisi tidak stabil atau rawan terjadi kelongsoran sehingga alternatif perkuatan bronjong (gabion) khususnya gabion box dengan sudut miring $48^{\circ}$ masih belum bisa diaplikasikan pada lereng embankment jalur kereta cepat Jakarta-Bandung DK70+150.00 sampai DK70+181.88.

\section{Stabilitas Lereng dengan Alternatif Perkuatan Geotextile}

Hasil output analisis stabilitas lereng embankment melalui aplikasi Plaxis 8.6 memiliki nilai safety factor sebesar $\Sigma \mathrm{SMF}=1,5007$. Sedangkan hasil analisis pemodelan lereng embankment dengan adanya pengaruh beban gempa memiliki nilai safety factor sebesar $\Sigma \mathrm{SMF}=1,1547$. Menurut output safety factor dapat dijelaskan bahwa nilai safety factor pemodelan lereng embankment alternatif perkuatan geotextile sesuai dengan cek stabilitas globalnya sudah memenuhi syarat dan dapat mengurangi penurunan tanah yang terjadi, tetapi angka safety factor hasil output hanya memiliki selisih sedikit dengan an- 
gka safety factor yang ditetapkan yaitu 0.0007. Sehingga dianggap cek stabilitas global dianggap masih belum memenuhi syarat ketentuan. Sedangkan dengan pengaruh beban dinamik gempa memiliki nilai hasil output yang memenuhi syarat cek stabilitas lereng sesuai SNI 8460-2017 Persyaratan Perancangan Geoteknik.

Penelitian Rozaq (2011) menjelaskan bahwa pemasangan perkuatan lereng tanah dengan geotextile mampu mengurangi penurunan yang terjadi pada struktur rel diatas subgrade tanah lunak.

Berdasarkan hasil analisis dan penelitian terdahulu yang telah dilakukan, bahwa alternatif perkutan menggunakan geotextile sudah mencukupi untuk penanganan longsor pada lereng embankmet karena dapat mengurangi penurunan yang terjadi pada struktur tanah dibawah rel. Sehingga dapat disimpulkan bahwa hasil analisis lereng embankment jalur kereta cepat Jakarta-Bandung DK70+150 sampai DK70+181.88 tersebut dengan alternatif perkuatan geotextile dalam keadaan stabil tetapi rawan terjadi kelongsoran.

\section{Stabilitas Lereng dengan Alternatif Kombinasi Perkuatan Gabion dan Micropile}

Output hasil running analisis pemodelan lereng embankment jalur kereta cepat Jakarta-Bandung DK70+150.00 sampai DK70+181.88 melalui program bantu Plaxis 8.6 berupa nilai safety factor sebesar $\Sigma \mathrm{SMF}=1,5416$. Sedangkan hasil output pemodelan lereng embankment alternatif gabion dan micropile akibat beban gempa memiliki nilai safety factor $\Sigma \mathrm{SMF}=1,3422$.

Berdasarkan rekapitulasi hasil output Tabel 4.22 dapat dijelaskan bahwa nilai safety factor hasil output analisis Plaxis 8.6 masih memenuhi standar minimum yang ditentukan baik akibat beban statis saja maupun adanya pengaruh akibat beban dinamik gempa. Sehingga menurut Peraturan Menteri Nomor 60 Tahun 2012. Syarat cek stabiltas secara global maupun cek stabilitas akibat beban dinamik gempa sudah memenuhi syarat yang berlaku, walaupun nilai safety factor pada cek stabilitas global berbeda tipis dengan nilai standart yang ditentukan. Maka diyatakan kondisi lereng stabil.

\section{Stabilitas Lereng dengan Alternatif Kombinasi Perkuatan Geotextile dan Micro- pile}

Berdasarkan output hasil running pemodelan lereng embankment menggunakan aplikasi Plaxis 8.6 yang dilakukan berdasarkan data desain gambar geometrik perencanaan jalur kereta cepat Jakarta-Bandung DK70+150.00 sampai DK70+181.88 dengan nilai stabilitas sebesar $\Sigma \mathrm{SMF}=1,8151$. Sedangkan hasil output dengan adanya pengaruh beban dinamik gempa memiliki nilai safety factor $\Sigma \mathrm{SMF}=1,6262$.

Menurut hasil penelitian dari Kemal (2017) hasil alternatif geotextile dengan micropile lebih efisien daripada metode keystone dengan geogrid. Hal tersebut dibuktikan dari output safety factor dan cek stabilitas yang memenuhi syarat.

Sehingga dapat disimpulkan bahwa lereng embankment dengan alternatif kombinasi 
perkuatan geotextile dan micropile menggunakan aplikasi Plaxis 8 kondisi stabil terhadap longsor karena memenuhi angka syarat cek stabilitas global dan cek stabilitas dinamik gempa yang telah ditentukan Peraturan Menteri Nomor 60 Tahun 2012 dan SNI 84602017 ketentuan standar minimum yang ditentukan yaitu $\geq 1,5$ untuk beban statis dan $\geq 1,1$ untuk beban dinamik gempa. Alternatif kombinasi perkuatan ini menggunakan micropile berfungsi untuk meningkatkan tahanan geser tanah dengan menahan gaya horizontal dan geotextile digunakan untuk menahan beban dari luar (eksternal) termasuk tekanan tanah lateral dari tanah dan beban yang akan bekerja pada badan jalannya

\section{Stabilitas Lereng dengan Alternatif Kombinasi Perkuatan Gabion dan Geotextile}

Output hasil running Tabel 6 menunjukkan pemodelan lereng embankment alternatif kombinasi perkuatan bronjong (gabion) dan geotextile melalui program bantu Plaxis 8.6 memiliki nilai stabilitas $\Sigma \mathrm{SMF}=1,7524$. Sedangkan hasil output dengan adanya pengaruh beban dinamik gempa memiliki nilai safety factor $\Sigma \mathrm{SMF}=1,5943$.

Berdasarkan hasil analisis cek stabilitas global dan cek akibat beban dinamik gempa alternatif perkuatan lereng embankment bronjong (gabion) dan geotextile memiliki nilai safety factor yang memenuhi standar minimum yang ditentukan Peraturan Menteri Nomor 60 Tahun 2012 dan SNI 8460-2017 Persyaratan Perancangan Geoteknik yaitu $\geq 1,5$ untuk beban statis dan $\geq 1,1$ untuk beban dinamik gempa. Sehingga dapat disimpulkan bahwa lereng embankment jalur kereta cepat Jakarta-Bandung DK70+150.00 sampai DK70+181.88 dalam kondisi stabil (lereng tahan terhadap kelongsoran) dengan solusi alternatif perkuatan kombinasi gabion dan geotextile. Tetapi hal ini dianggap kurang efisien karena kedua alternatif perkuatan hanya berfungsi menahan beban dari luar (eksternal) termasuk tekanan tanah lateral dari tanah dan beban yang akan bekerja pada badan jalannya secara vertikal saja.

\section{Stabilitas Lereng dengan Alternatif Kombinasi Perkuatan Gabion, Geotextile dan Micropile}

Sesuai Tabel 6 hasil running analisis dengan Plaxis 8.6 dengan pemodelan lereng alternatif kombinasi dari Gabion, Geotextile dan Micropile menghasilkan nilai safety factor sebesar $\Sigma \mathrm{SMF}=1,9463$. Sedangkan hasil output Plaxis 8.6 dengan pengaruh beban dinamik gempa memiliki nilai safety factor sebesar $\Sigma \mathrm{SMF}=1,7594$. Sesuai Persyaratan Perancangan Geoteknik dan Peraturan Menteri Nomor 60 Tahun 2012 menjelaskan bahwa nilai safety factor lereng embankment jalur kereta cepat Jakarta-Bandung pada DK70+150.00 sampai DK70+181.88 memiliki nilai safety factor $\geq 1,5$ untuk beban statis dan $\geq 1,1$ untuk beban dinamik gempa. Sehingga dapat disimpulkan bahwa pada lereng embankment dengan alternatif perkuatan gabion, geotextile dan micropile dalam kondisi aman atau stabil dari kelongsoran. Namun kombinasi alternatif tersebut dianggap tidak efisien karena menggunakan fungsi ganda dalam mengurangi kelongsoran lereng. Solusi 
alternatif ini juga dianggap boros karena menggunakan alternatif gabion dan geotextile dalam satu lereng embankment sekaligus untuk meminimalisir pergerakan tanah akibat beban dari luar (eksternal) termasuk tekanan tanah lateral dari tanah dan beban yang akan bekerja pada badan jalannya.

\section{SIMPULAN}

Hasil akhir penelitian analisis stabilitas lereng embankment kereta api cepat JakartaBandung DK70+150.00 sampai DK70+181.88 yang dimodelkan dengan program bantu Plaxis 8.6, diperoleh kesimpulan dari jawaban rumusan masalah dalam penelitian ini yaitu:

Nilai safety factor hasil analisis pemodelan lereng embankment kondisi eksisting/asli kereta api cepat Jakarta-Bandung DK70+150.00 sampai DK70+181.88 secara cek global sebesar $\Sigma \mathrm{MSF}=1,1565 \leq 1,5$, sedangkan hasil cek dinamik akibat gempa sebesar $\Sigma$ MSF $=1,0515 \leq 1,1$. Menurut Permen No 60 Tahun 2012 dapat disimpulkan bahwa lereng embankment kondisi eksisting/asli jalur kereta cepat Jakarta-Bandung DK70+150 sampai DK70+181.88 saat menerima beban layan lereng mengalami kondisi tidak stabil dan terjadi kelongsoran. Sehingga harus dilakukan penambahan alternatif perkuatan sebagai upaya meminimalisir kelongsoran.

Berdasarkan simulasi penambahan alternatif perkuatan menggunakan aplikasi Plaxis 8.6 menghasilkan Output safety factor micropile $\Sigma \mathrm{SMF}=1,0751$, gabion $\Sigma \mathrm{SMF}=1,1070$, geotextile $\Sigma \mathrm{SMF}=1,1547$, micropile dengan gabion $\Sigma \mathrm{SMF}=1,3422$, micropile dengan geotextile $\Sigma \mathrm{SMF}=1,6262$, gabion dengan geotextile $\Sigma \mathrm{SMF}=1,5943$ dan micropile gabion dengan geotextile $\Sigma \mathrm{SMF}=1,7594$. Penambahan alternatif kombinasi perkuatan geotextile dengan micropile paling memungkinkan untuk digunakan pada kondisi jalur kereta cepat Jakarta-Bandung DK70+150.00 sampai DK70+181 dengan $\Sigma$ SMF $=1,8151$ (cek stabilitas global) dan $\Sigma \mathrm{SMF}=1,6262$ (cek stabilitas akibat beban dinamik gempa).

\section{DAFTAR RUJUKAN}

Andy Simatupang, Rudi Iskandar. 2012. Perbandingan Antara Metode Limit Equilib rium dengan Metode Finite Element dalam Analisa Stabilitas Lereng. Pdf: Universi tas Sumatera Utara.

Christiady, Hary. 2010. Mekanika Tanah I (Edisi kelima). Yogyakarta: Gadjah Madan University Press.

Christiady, Hary. 2010. Mekanika Tanah II (Edisi kelima). Yogyakarta: Gadjah Madan University Press.

Christiady, Hary. 2010.Penanganan Tanah Longsor dan Erosi. Yogyakarta: Gadjah Madan University Press.

Direktorat Jendral Bina Marga dan Direktorat Bina Teknik. 2009. Modul Pelatihan Ge osintetik Volume 3 Perencanaan Geosintetik untuk Perkuatan Lereng. Jakarta: Ke 
Menterian Pekerjaan Umum.

Ellis, E., Hai-Sui Yu, G., McDowell, A. Dawson \& N. Thom. 2008. Advansces in Trans portation Geotechnics. Proceedings of The 1st International Conference on Transpor tation Geotechnics, Nottingham UK. London: CRS Press Taylor \& Francis Group.

FHWA. 2001. Mechanically Stabilized Earth Walls and Reinforced Soil Slopes Design and Construction Guidelines. FHWA-NHI-00-043.

Herman, Dave Juven G., 2012. Analisis Stabilitas Lereng Limit Equilibrium vs Finite Element Method. Procceding Konferensi Nasional Geoteknik Indonesia ke 16, Him punan Ahli Teknik Tanah Indonesia. Jakarta

Koerner, Robert. M. 2005. Designing with Geosynthetics. New Jersey: Pearson Prentice Hall.

Lawrence, Martha., Liu, Ziming. 2016. China’s High-Speed Rail Develompent. Wash ington: Transport Global Practice Central Asia, China, and Mongolia The World Bank.

Maccaferri. 1987. Flexible Gabion Structures in Earth Retaining Works. Bologna, Italy.

M. Das, Braja. 1994. Mekanika Tanah Jilid I. Surabaya: Erlangga.

M. Das, Braja. 1994. Mekanika Tanah Jilid II. Surabaya: Erlangga.

M. Das, Braja. 1998. Principles of Foundation Engineering 4th Edition. Pacific Grove: PWS Publishing.

M. Das, Braja. 2002. Principles of Geotechnical Engineering 5th Edition. Pacific Grove: PWS Publishing.

Muzakki, Fauzan. 2017. Analisa Bahaya Longsor Area Rencana Pembangungan Jalur

Kereta Cepat Jakarta Bandung CK88-CK114 Kabupaten Bandung Barat. Bogor: Institut Pertanian Bogor.

Peraturan Menteri Perhubungan. 2012. PM No. 60: Persyaratan Teknis Jalur Kereta Api. Jakarta: Menteri Perhubungan Republik Indonesia

Razaq, Abdul. 2011. Penurunan Struktur Rel Kereta Api Di Atas Tanah Lunak Dengan Perkuatan Geosintetik. Surakarta: Universitas Sebelas Maret.

Rusdiansyah. 2016. Asumsi Sistem Cerucuk Sebagai Alternatif Solusi dalam Penanga nan Kelongsoran Lereng Jalan diata Tanah Lunak. Banjarmasin: Universitas Lam bung Mangkurat

S.G. Zhang. 2007. The Fundamental Theory and Engineering Technique of High-Speed Train. Beijing: Science Publisher (in Chinese) 
JURNAL BANGUNAN, VOL. 26, NO.1, MARET 2021: 29-44 